\title{
The Information Needs and Seeking Behaviour of The Tamil Nadu Dr. Ambedkar Law University Faculty Members
}

\author{
S. Thanuskodi \\ Library \& Information Science Wing, Directorate of Distance Education, Annamalai University, 608002, Annamalai Nagar
}

\begin{abstract}
Adequate knowledge about the information needs and seeking behaviour of users is vital for developing library collections, services and facilities to meet their information needs effectively. The purpose of this study is to identify the information channels used by the Tamil Nadu Dr. A mbedkar Law University faculty members, information sources preferred by them, methods employed for getting the needed information and their library use pattern. A questionnaire was distributed to 20 Tamil Nadu Dr. A mbedkar Law University faculty members and 18 filled in questionnaires were returned, giving an overall response rate of 90 percent. It was found that respondents used various sources for acquiring the needed information. Books were ranked as the most important source for teaching and research purposes, followed by law reports and statutes. Respondents preferred to first consult their personal collection before resorting to other information providing sources and agencies. The Online Public Access Catalogue (OPAC) and CD-ROM were the most frequently used IT-based sources and facilities. E-mail was the most popular among the Internet-based services and applications. On the whole, respondents perceived Tamil Nadu Dr. Ambedkar Law University library collections, services and facilities as adequate to meet their information needs effectively.
\end{abstract}

Keywords Information Seeking Behaviour; Information Needs; Information Channels, Internet, E-Mail, CD-ROM

\section{Introduction}

Information is considered as an important resource that contributes towards the development of a nation. It provides the core for the development of knowledge, the basis for innovations, the resources for informed citizenry, and as a result, becomes a key commodity for the progress of a society. Acknowledging the significance of information in national development, Wasserman (1991, p. 38) noted that "it is not an accident that the developed nations are those in which information products and services have been brought into being and are widely exploited, first in conventional forms and later through computer intervention". Members of a society acquire the needed information from a variety of sources. However, several of these sources are expensive, complex or difficult for individuals to acquire and use. Therefore, the role of libraries becomes vital in meeting the information needs of individuals in the society. Libraries develop their collections, facilities and services to meet the information needs of their patrons. However, in order to accomplish this task effectively, libraries must have a

* Corresponding author:

thanuskodis@yahoo.com (S. Thanuskodi)

Published online at http://journal.sapub.org/ijis

Copyright (C) 2012 Scientific \& Academic Publishing. All Rights Reserved thorough understanding of the information needs and information-seeking behaviour of their users.

Information seeking behaviour is a broad term, which involves a set of actions that an individual takes to express information needs, seek information, evaluate and select information, and finally use this information to satisfy his/her information needs. Various factors may determine the information seeking behaviour of an individual or a group of individuals. It is, therefore, desirable to understand the purpose for which information is required, the environment in which the user operates, users' skills in identifying the needed information, channels and sources preferred for acquiring information, and barriers to information. Adequate knowledge of the information needs of users is imperative for libraries in re-orienting their collections, services and activities to synchronise them with the information seeking behaviour of their patrons. Bandara (1993, p. 19) noted that 'if the library is to provide any meaningful information service, the user[information seeking] habits should be taken into consideration". Since the 1940s, numerous studies have been conducted investigating different aspects of this topic. Earlier studies primarily focused on scientists and technologis ts to assist in build ing in formation resources and systems to effectively meet their information needs (Reneker, 1992). Hart (1993) felt that earlier studies focused on scientists and engineers because of more interest in these libraries at that 
time and greater availability of funds. Later on, the scope of information seeking studies expanded to include scholars and academics fro $m$ other disciplines.

\section{Review of Literature}

Many studies have been conducted to investigate the information-s eeking behaviour of library users based on their subject interest, occupation, information environment, and geographical location. Information needs and seeking behaviour of academics have also been a popular area of research. Many earlier studies reported that scholars and academicians heavily used books and journals. Hart investigated the degree to which academicians and scholars in different disciplines vary in their dependence on books and journals. A questionnaire was sent to 167 faculty members and 140 responded. It was found that $14 \%$ of the faculty members from science stream, $13 \%$ from social sciences and $21 \%$ from humanities relied more on books. On the other hand, $53 \%$ of the faculty members from science, $33 \%$ from social science, and $7 \%$ from humanities relied more on journals. Equal importance to books and journals was given by $33 \%$ academics from science, $54 \%$ from social sciences and $74 \%$ from humanit ies[1].

Sethi used a questionnaire to study the information-s eeking behavior of 256 social science faculty members in Indian universities. It was found that respondents preferred journals, books, government documents and reference sources for meeting their information needs. The study also revealed lesser use of indexing and abstracting sources, book reviews, conference proceedings, dissertations and theses, newspaper clippings and other non-book sources[2]. However, Prasad noted that in addition to journal articles, non-traditional literature such as unpublished conference and symposia papers, research proposals, policy guidelines, and project reports were equally popular among the scholars. Many studies have shown that in additional to formal information sources, academics also relied heavily on informal communication channels to meet their information needs [3].

Al-Shanbari and Meadows reported that 36 percent of the academicians in Saudi universities were spending four hours per week on reading, whereas, almost three-quarters of the respondents were spending the same amount of time on communicating with their colleagues. The study concluded that scholars in developing countries prefer informal channels for acquiring the needed information because of inadequate and irrelevant library collections, lack of information infrastructures, ineffective library services, lack of money to use fee-based information services, inadequately trained and less co-operative library staff. Some studies investigating the information seeking behaviour of scholars and academics have examined the role of the library in relation to other information providers[4]. Smith reported that about one-half of the respondents from Pennsylvania State University relied more on their personal collections and borrowing materials from other libraries [5]. Guest noted that
$85 \%$ of the respondents relied on their personal collection as a major source for information for teaching and research. The author also found that librarians were rated the lowest as a source for getting the needed information. The success of a library in meeting the information needs of its user plays an important role in the number of their future library visits[6].

Mwila used a questionnaire to study the use of University of Zambia library by its faculty for teaching and research purposes. It was found that humanities and social science faculty members used library more often compared to science faculty members[7]. Majid, Anwar and Eisenschitz, found that nearly $42 \%$ of the respondents from University Putra Malaysia visited their library once or twice a week, $37 \%$ once or twice a month and $21 \%$ several times a year[8].

Bane and Melheim investigated the use of Internet by academics. A questionnaire was sent through the Internet to 231 rando mly selected discussion groups. A total of 15,361 questionnaires were returned through email. Results of the survey disclosed that personal e-mail was utilized extremely often, more than once a week by nearly $90 \%$ of the respondents. Discussion groups were accessed more than once a week by $75 \%$ of the respondents. Electronic journals were accessed far less frequently more than once a week by $23 \%$ of the respondents.[9].

\section{Methodology}

The study used questionnaire-based survey method, as many similar studies conducted earlier, have also used this method for data collection. This method is also preferred as it was less time consuming and economical for a scattered population. The population of the study consisted of all academic staff working in the Tamil Nadu Dr. Ambedkar Law University. The survey instrument consisted of two sections. Section 1 collected data on personal information about the respondents such as gender, academic rank,

highest qualification and teaching experience. Section 2 of the questionnaire, compris ing 10 questions, collected data on the information seeking behavior of the respondents. Questions in this section focused on the following areas: information sources used by the respondents, use of Tamil Nadu Dr. A mbekdar Law University library, adequacy of library collections, library use and computing skills of respondents, and the use of IT-based library sources and services. In order to ensure reliability and effectiveness of the instrument, the questionnaire was pilot tested on ten postgraduate students of the Tamil Nadu Dr. Ambekdar Law University. The pre-testing exerc ise was undertaken to identify any problems that potential respondents might face in understanding questions posed to them. Results of the pilot study showed that respondents were able to understand the questions and their responses were interpretable. In order to save time and ensure better response rate, the questionnaires were personally distributed to the academic staff in their offices in April 2011. A total of 18 filled-in questionnaires were received, showing an overall response rate of 90 percent. 


\section{Results and Discussion}

\subsection{Library Use Skills of the Respondents}

Table 1. Library Use Skills of Respondents

\begin{tabular}{|c|c|c|}
\hline Skill Level & Number & Percentage \\
\hline Excellent & - & - \\
\hline Very Good & 8 & 44.44 \\
\hline Good & 4 & 22.22 \\
\hline Fair & 6 & 33.34 \\
\hline Poor & - & - \\
\hline
\end{tabular}

Respondents were asked to provide self-assessment on their level of library use skills. It was assumed that library use skills might have a bearing on the ways respondents use the library to acquire the needed information. Those respondents who have better library use skills were expected to utilise library resources and facilities more effectively compared to those with poor lib rary use skills. Data analys is showed that $8(44.44 \%)$ of the respondents assessed their library use skills as 'very good', $4(22.22 \%)$ as 'good' and 6 $(33.34 \%)$ as fair (Table 1$)$. None of the respondents perceived their library use skills as 'excellent' or 'poor'.

\subsection{Computing Skills of Respondents}

Table 2. Computing Skills of Respondents

\begin{tabular}{|c|c|c|}
\hline Skill Level & Number & Percentage \\
\hline Excellent & 4 & 22.22 \\
\hline Very Good & 3 & 16.67 \\
\hline Good & 7 & 38.89 \\
\hline Fair & 4 & 22.22 \\
\hline Poor & - & \\
\hline
\end{tabular}

Respondents were also asked to provide self-assessment on their level of computer use skills. It was assumed that level of computing skills might have an impact on their use of IT-based library sources and facilities. Of the 18 respondents, $4(22.22 \%)$ perceived his/her computing skills as 'excellent', 3 (16.67\%) 'very good' and 7 (38.89\%) as 'good' (Table 2). $4(22.22 \%)$ of the respondents considered their computing skills as 'fair'.

\subsection{Infor mation Channels Used by Respondents}

Table 3. Use of Information Channels by Respondents

\begin{tabular}{|c|c|c|c|c|}
\hline Channels & Always & Frequently & Occasionally & Never \\
\hline $\begin{array}{c}\text { Personal } \\
\text { Collection }\end{array}$ & $\begin{array}{c}14 \\
(77.78 \%)\end{array}$ & $\begin{array}{c}3 \\
(16.67 \%)\end{array}$ & $\begin{array}{c}1 \\
(5.55 \%)\end{array}$ & - \\
\hline $\begin{array}{c}\text { University } \\
\text { Library }\end{array}$ & $\begin{array}{c}8 \\
(44.44 \%)\end{array}$ & $\begin{array}{c}6 \\
(33.33 \%)\end{array}$ & $\begin{array}{c}4 \\
(22.22 \%)\end{array}$ & - \\
\hline Colleagues & $\begin{array}{c}3 \\
(16.67 \%)\end{array}$ & $\begin{array}{c}2 \\
(11.12 \%)\end{array}$ & $\begin{array}{c}4 \\
(22.22 \%)\end{array}$ & $\begin{array}{c}9 \\
(50 \%)\end{array}$ \\
\hline Book Stores & $\begin{array}{c}2 \\
(11.12 \%)\end{array}$ & $\begin{array}{c}3 \\
(11.12 \%)\end{array}$ & $\begin{array}{c}11 \\
(16.67 \%)\end{array}$ \\
\hline
\end{tabular}

Respondents were asked to indicate in formation channels first consulted by them for getting the needed information. It was found that $77.78 \%$ of the respondents 'always' first consulted their personal collections. Of the 18 respondents, 8 $(44.44 \%)$ reported 'always' and 6 (33.33\%) 'frequently' visiting the University library for meeting their information needs. The percentages of respondents 'always' and 'frequently' approaching their colleagues were $16.67 \%$ and $11.12 \%$ respectively. Data analys is suggested that faculty members preferred to first consult their personal collection for meeting their information needs followed by library and colleagues.

\subsection{Libr ary Visits}

Table 4. Computing Skills of Respondents

\begin{tabular}{|c|c|c|}
\hline Visit Frequency & Number & Percentage \\
\hline Almost Daily & 2 & 11.11 \\
\hline Once or twice a week & 7 & 38.89 \\
\hline Once or twice a month & 5 & 27.77 \\
\hline Several times a year & 4 & 22.23 \\
\hline Never & - & - \\
\hline
\end{tabular}

Respondents were asked how often they visited the library. Of the 18 participants who responded to this question, 7 $(38.89 \%)$ visited the library at least one or twice a week (Table 4). Another $5(27.77 \%$ ) respondents visited the library at least once or twice a month. It was also found that $53.23 \%$ of the male and $46.77 \%$ of the female respondents visited the library at least one or twice a week. A cross-tabulation between the number of library visits and library use skills of respondents was made to find out if any trend existed between these two

variables. It was found that $81.3 \%$ of the respondents with 'very good' and 55.5\% with 'good' library use skills visited their lib rary once or twice a week. On the contrary, only 38. $5 \%$ of the respondents with 'fair' library use skills made the same number of library $v$ isits. It appears that user with better library use skills are likely to visit library more frequently compared to those with low library use skills.

\subsection{Methods of Getting Infor mation from the Library}

Table 5. Methods used for Getting Information from the Library (Multiple Responses)

\begin{tabular}{|c|c|c|c|}
\hline Methods & Always & Frequently & Occasionally \\
\hline Going Library Personally & 8 & 5 & 5 \\
\hline Calling the Library & 3 & 4 & 11 \\
\hline Sending Students & 2 & 2 & 14 \\
\hline Sending Support Staff & 5 & 3 & 10 \\
\hline
\end{tabular}

Respondents were asked to indicate methods employed by them for getting information from the University library. A 11 respondents, with varied frequencies, personally visited their library for getting the needed information (Table 5). Three respondents reported calling the library for this purpose. Two faculty members asked their students and five sent support staff to get information from the library. It appeared that in addition to visiting the library, faculty members also used certain other methods for getting information from the lib rary.

\subsection{Importance of Infor mation Sources to Te aching}


Table 6. Importance of Information Sources for T eaching

\begin{tabular}{|c|c|c|c|}
\hline \multirow{2}{*}{ Information Source } & \multicolumn{2}{|c|}{ Gender } & \multirow{2}{*}{ Total } \\
\cline { 2 - 3 } & Male & Female & \\
\hline Books & 4.22 & 2.52 & 4.02 \\
\hline Law Reports & 4.1 & 2.66 & 3.75 \\
\hline Statutes & 3.44 & 2.78 & 3.56 \\
\hline Research Articles & 4.36 & 2.85 & 4.10 \\
\hline Review Articles & 4.56 & 2.66 & 4.23 \\
\hline Legal Digests & 2.52 & 3.21 & 2.99 \\
\hline Conference Abstracts \& Proceedings & 4.65 & 3.1 & 2.90 \\
\hline Abstracting and Indexing Sources & 4.15 & 2.44 & 3.81 \\
\hline Theses and Dissertations & 4.56 & 2.58 & 3.04 \\
\hline Encyclopaedias & 4.21 & 3.39 & 3.77 \\
\hline Total & 4.46 & 2.78 & 4.15 \\
\hline
\end{tabular}

Respondents were asked how important are different information sources for their teaching. A study of data in table- 6 indicates the gender wise respondents' importance of information sources for teaching. The male respondents occupy the first position with respect to their overall importance of information sources for teaching as their secured mean score is 4.46 on a 5 point rating scale. The female respondents take the second position in their overall importance of information sources for teaching as their secured mean score is 2.78 on a 5 point rating scale. It could be seen clearly from the above discussion that male respondents take the first position in their overall importance of information sources for teaching, and female respondents take the second position.

\subsection{Ade quacy of Library Collections}

Table 7. Adequacy of Library Collections

\begin{tabular}{|c|c|c|c|}
\hline \multirow{2}{*}{ Collection Type } & \multicolumn{2}{|c|}{ Gender } & \multirow{2}{*}{ Total } \\
\cline { 2 - 3 } & Male & Female & \\
\hline Law Reports & 4.46 & 2.99 & 4.15 \\
\hline Statutes & 3.52 & 2.26 & 3.37 \\
\hline Journals & 3.37 & 3.87 & 4.10 \\
\hline Books & 2.52 & 2.42 & 2.56 \\
\hline Reference Materials & 3.15 & 3.05 & 3.96 \\
\hline CD-ROM Databases & 2.15 & 3.49 & 2.75 \\
\hline Audio-visual Materials & 4.42 & 2.40 & 3.90 \\
\hline Total & 3.52 & 2.18 & 2.80 \\
\hline
\end{tabular}

Respondents were asked to provide their ass essment of the adequacy of the Tamil Nadu Dr. A mbedkar Law University library collections in meeting their information needs. A study of data in table-7 indicates the gender wise respondents' adequacy of library collections. The male respondents occupy the first position with respect to their overall adequacy of library collections as their secured mean score is 3.52 on a 5 point rat ing scale. The female respondents take the second position in their overall adequacy of library collections as their secured mean score is 2.18 on a 5 point rating scale. It could be seen clearly from the above discussion that male respondents take the first position in their overall adequacy of library collections and female respondents take the second position.

\subsection{Use of Internet}

Table 8. Use of the Internet-based Services and Applications

\begin{tabular}{|c|c|c|c|}
\hline Internet-based Services and Applica- & \multicolumn{2}{|c|}{ Gender } & \multirow{2}{*}{ Total } \\
\cline { 2 - 3 } tions & Male & Female & \\
\hline Electronic mail & 4.26 & 3.86 & 4.01 \\
\hline $\begin{array}{c}\text { Electronic information sources (e.g. } \\
\text { electronic journals, contents pages) }\end{array}$ & 4.22 & 2.96 & 3.90 \\
\hline $\begin{array}{c}\text { OPACs of local and overseas univer- } \\
\text { sities }\end{array}$ & 4.05 & 2.96 & 3.51 \\
\hline $\begin{array}{c}\text { Electronic bullet in boards and discus- } \\
\text { sion groups }\end{array}$ & 2.77 & 3.89 & 3.16 \\
\hline File transfer protocols (ftp) & 3.56 & 2.42 & 2.96 \\
\hline Total & 3.89 & 2.96 & 3.18 \\
\hline
\end{tabular}

A study of data in table- 8 indicates the gender wise respondents' use of the Internet-based Services and Applications. The male respondents occupy the first position with respect to their overall use of the Internet-based Services and Applications as their secured mean score is 3.89 on a 5 point rating scale. The female respondents lag behind the male respondents in their overall use of the Internet-based Services and Applications as their secured mean score is 2.96 on a 5 point rating scale. It could be seen clearly from the above discussion that male respondents take the first position in their overall use of the Internet-based Services and Applications and female respondents lag behind the male respondents.

\subsection{Library Effectiveness}

Table 9. Overall Effectiveness of the University Library

\begin{tabular}{|c|c|c|}
\hline Effect iveness Level & Number & Percentage \\
\hline Very effective & 3 & 16.67 \\
\hline Effect ive & 9 & 50.00 \\
\hline Somewhat effective & 6 & 33.33 \\
\hline Ineffect ive & - & - \\
\hline Very ineffect ive & - & - \\
\hline
\end{tabular}

Respondents were asked to provide their overall assessment of the effectiveness of Dr. Ambedkar Law University library in meeting their information needs. Out of the 18 participants, 3 considered the library 'very effective' in meeting their information needs (Table 9) and 9 considered the library 'effective' in meeting their information needs. Another 6 (33.33\%) of the respondents perceived the library as 'somewhat effective'. None of the respondents assessed the library as 'ineffective'. It appeared that a majority of the law faculty members were satisfied with the collections, services and facilities provided by the Dr. A mbedkar Law University library for meeting their information needs.

\section{Conclusions}

The study investigated the information needs and information-seeking behaviour of law faculty members at the Dr. Ambedkar Law University. It was found that respondents used a variety of information sources for teaching and research. Books, law reports and statutes were considered more important. It is interesting to note that, although respondents perceived the Dr. Ambedkar Law University 
library as effective in meeting their information needs, they prefer to first consult their personal collections. It might be due to easy and convenient access to the personal collection and/or unawareness about library collections, services and facilities. The study revealed that the respondents used IT-based library sources and facilities less frequently compared with printed sources. It might be due to the lack of awareness about their availability, improper selection of materials or unfamiliarity with these products. Similarly, it is also noted that e-mail is the most popular Internet application, whereas other Internet-based services and applications are only used by a limited number of respondents. This is a matter of concern, as presently, electronic information sources and the Internet are considered extremely important tools for effective teaching and research. Therefore, the Dr. Ambedkar Law University library might like to review its electronic information resources, while at the same time embark on an extensive library pro motion and user education programme.

\section{REFERENCES}

[1] Hart, R.L. The information-gathering behaviour of the faculty of a four-y ear state college. Ph.D. Thesis : University of North Carolina, 1993.
[2] Sethi, A. Information seeking behaviour of social scientists: an Indian conspectus. New Delhi : Hindustan Publishing Corporation, 1990.

[3] Prasad, H.N. Information seeking behaviour of physical scientists and social scientists: a report. Annals of Library Science and Documentation, Vol. 45, no. 2: 41-48, 1998.

[4] Al-Shanbari, H. and Meadows, A.J. Problems of communication and information-handling among scientists and engineers in Saudi Universities. Journal of Information Science, Vol. 21, no. 6: 473-478, 1995.

[5] Smith, E.S. Document supply: developments and problems. IAALD Quarterly Bulletin, Vol. 32, no.1: 19-23, 1987.

[6] Guest, S.S. The use of bibliographic tools by humanities faculty at the State University of New York at Albany. Reference Librarian, Vol. 18:157-172, 1987.

[7] Mwila, A.B. The use of the University of Zambia library by the social science, humanities and science faculties. Ph.D. thesis, University of Michigan, 1993.

[8] Majid, S.; Anwar, M.A. and Eisenschitz, T.S. Information needs and seeking behavior of agricultural scientists in Malay sia. Library and Information Science Research, Vol. 22, no. 2: 145-163, 2000.

[9] Bane, A.F. and Milheim, W.D. Internet insights: how academics are using the Internet. Computers in Libraries, Vol. 15, 2:32-36, 1995. 